\title{
"Ordinary Man": Christy Moore and the Irish Protest Ballad
}

\author{
MIKE INGHAM
}

\section{Introduction: Contextualizing the Modern Ballad}

In his critical study, The Long Revolution, Raymond Williams identified three definitions of culture, namely idealist, documentary, and social. He conceives of them as integrated strands of a holistic, organic cultural process pertaining to the "common associative life" ${ }^{1}$ of which creative artworks are an inalienable part. His renowned "structure of feeling" concept is closely related to this theoretical paradigm. The ballad tradition of popular and protest song in many ethnic cultural traditions exemplifies the core of Williams's argument: it synthesizes the ideal aesthetic of the traditional folk song form as cultural production, the documentary element of the people, places, and events that the song records and the contextual resonances of the ballad's source and target cultures. Likewise, the persistence and durability of the form over many centuries have ensured its survival as a rich source for ethnographic studies and an index of prevailing socio-political conditions and concerns.

As twentieth-century commentators on the Anglophone ballad form, such as A. L. Lloyd, have observed, there is an evident distinction between the older ballad tradition, tending toward a more impersonal and distanced voice and perspective, and the more personal style of ballad composed after the anthropological research of ethnomusicologists such as Cecil Sharp, Alan Lomax, and others during the first half of the twentieth century. The former derives from a continuous lineage of predominantly anonymous or unattributed folk material that can be said to reside in the public domain, and largely resists recuperation or commodification by the music industry. Such ballads belong to the audience and the performers at the point of any given iteration, and, though created afresh in each specific rendition and interpretation, are recognizably part of a shared popular heritage, carrying egalitarian, grass-roots associative connotations, as opposed to socially hierarchical ones. The conventions and commonplaces of the form-often consisting of stock imagery and tropes-tend to be valued less for their original literary features and more for their recognition factor and their propensity for signifying cultural continuity. Primarily associated with traditions of orality and oral transmission, these songs have been kept alive by becoming deeply rooted cultural memes in the ever-churning pool of popular music material.

By contrast, the more contemporary new ballad is distinguished by the mark of authorship and ownership via copyright, even where the copyright may be readily waived for performance, and the music shared online and in other formats and contexts. The vast majority of the commonly known and commonly shared post-WWII ballads have credited composers, and, for the most part, these are the bestknown interpreters of the songs. Ballads written and performed by the likes of Leadbelly, Woody Guthrie, Ewan MacColl, Pete Seeger, Peggy Seeger, Bob Dylan, Phil Ochs, Billy Bragg, and Sinéad O’Connor tend to bear the authentic stamp of their own specific interpretation, even if alternative renditions by other

\footnotetext{
${ }^{1}$ Williams, The Long Revolution (Calgary: Broadview Press, 2001), 55. 
well-known performers are familiar to audiences. Other iconic ballad performers on the transatlantic folk scene of the past sixty years, including the Watersons, The Weavers, Joan Baez, Martin Carthy, Fairport Convention, Pentangle, and Steeleye Span, have been more noted for their innovative musical arrangements, vocal harmonies, and-in the case of the last three referenced-their use of electric guitars and an eclectic folk-blues-rock sound, than for their creative contribution in the matter of lyrics and ballad topics.

Arguably, then, the solo singers cited above who have created new and original ballads during their performing careers have helped to redefine and reinvigorate the ancient genre. Often idiosyncratic and distinctive to the vocal and songwriting style of the singer-songwriter, such modern ballads evince considerable commonalities with the more traditional variety, particularly the political broadside subgenre. At the same time, they partake of a structure of feeling that connects them with successive younger generations of audiences. This is equally true of contemporary traditionalist interpreters such as the awardwinning Sam Lee, whose band explores sonorities that engage with modern jazz, employing musical soundscapes pioneered by earlier new-wave folk artists, such as Nick Drake and John Martyn, as well as the Irish Celtic folk and jazz group Moving Hearts, with whom Christy Moore sang in the early 1980s.

Despite this type of creative infusion, the debate persists about the value of the older traditional Anglophone ballads, as compared with the upstart "new" ballads found in the repertoires of modern and contemporary singer-songwriters. The modern variety doesn't always gain acceptance among advocates of folkloric purity and authenticity, even if twentieth and twenty-first century compositions by contemporary balladeers have become largely accepted in virtually all urban folk-singing contexts and most rural ones. That this is not the case universally is beautifully demonstrated by Paul Fegan's 2016 documentary Where You're Meant to Be. The film follows Scottish singer-raconteur Aidan Moffat in his travels around Scotland performing various rewritten or adapted versions of some of the most famous songs culled from the Scottish highland and borders traditional songbook. Moffat's free renditions don't find favor with 79-yearold traveling balladeer, Sheila Stewart, who challenges what she sees as Moffat's self-indulgent policy of playing fast and loose with the ballad heritage; through their temporary itinerant relationship Moffat is persuaded to revise his attitude toward traditional song in an amusing, but ethnographically resonant, encounter.

One major difference between the traditional ballad and its modern or contemporary counterpart lies in the iconography of the singer-songwriter and recording artist, which inevitably impinges upon the reception and perception of the song itself. Even though faded images of celebrated ballad-singers of past times are sometimes reproduced in digital media, these cannot compare with the iconographic media representations of more contemporary artists. Similarly, texts and tunes of unknown provenance and uncertain authorship appear to lack the immediacy and, occasionally, controversy that often surround contemporary protest songwriting. In this latter-day context of cultural hybridity and sonic fusion, it is sometimes easy to detect the feeling, but harder to identify or engage with the structural framework and tradition. Although the modern protest song popularized by the folk revival of the 1950s and 60s shared various features with the ballad, including a significant socio-political agenda, its more rhetorical and direct address to the listener differentiates it from the narrative ballad with its often allusive and oblique frame of reference. Thus, the 1960s protest song of counter-cultural resistance bore various features in common with the protest ballad tradition, but its aims, context, and, crucially, audience were not identical.

Another source of confusion is the indiscriminate application of the genre term "ballad" to denote a slow, generally romantic, composition. This slippage of terminology has tended to result in the 
marginalization of the narrative ballad of social (in)justice with its roots in critique, activism, and ideological resistance. The confusing contemporary usage of the term with reference to lyrical, slowertempo songs by pop and rock music performers is pervasive, and ultimately serves to obscure the conventional meaning for a wider public; arguably, this process reflects the power of the media machine in its commonly pro-establishment imperatives and strategies.

Today the category of ballad embraces a gamut of song types, ranging from traditional folk ballads still in circulation, newly created ballads penned by singer-songwriters and alternative quasi-ballads from Dylan's "Ballad in Plain D" (1964) and "Ballad of a Thin Man" (1965), Georgie Fame's "The Ballad of Bonnie and Clyde" (1967) and John Lennon's “The Ballad of John and Yoko" (1970) to songs simply calling themselves ballads, such as American steampunk band Panic at the Disco's "The Ballad of Mona Lisa” (2011). In some cases a rock ballad, such as U2's 2008 tribute to the deceased singer of fellow-Irish band The Dubliners, "The Ballad of Ronnie Drew," may actually conform to a ballad structure, narrative, and ethos.

Clearly, therefore, a necessary critical distinction needs to be made between ballad-oriented songs of the type discussed above and slower pop and rock numbers generically and indiscriminately-but popularly-referred to as ballads. For aficionados of folk-based and alternative popular songs and people involved in what has been described as "roots music," the cultural replacement process of the one by the other has been less sweeping. In such circles the ballad, whether traditional or "new-old style"—as Irish singer Sinead O'Connor entitled her 2002 collection of roots-influenced songs, "Sean-Nós Nua"remains a potent form of cultural intervention and commentary. Despite these perhaps critically underappreciated developments of the past seventy years or so in the ballad's evolution, certain residual, embedded properties, and conventions remain constant: those of form, voice, point of view, narrative technique and, above all, of social identification and commitment. Recording the experiences of ordinary people, expressing their interests, attitudes, and quotidian lives, voicing out social protest at their oppression and exploitation, all are the province of the ballad.

\section{Christy Moore and the Irish Ballad Tradition}

As Anglophone ballad and folk specialists such as A.L. Lloyd have observed, Irish and English ballad genealogies are in some respects similar, but in others very different. There is no doubt that, as Lloyd puts it, "a huge repertory of Anglo-Irish melody evolved, although it is not always clear on which side of the Irish Channel its components were forged." ${ }^{2}$ The English traditional and broadside ballads were more closely related to gender and class inequality and tyranny on the part of the ruling classes, although amatory ballads and ballads of domestic tragedy tended to form the staple of ballad-singers and composers. Certainly, the Irish tradition has had its counterparts, and many non-political songs are included in the repertoires of Moore and other Irish ballad singers. However, the ballad tradition in Ireland has also been profoundly marked by the colonizer-colonized relationship in the land, recounting the recurrent violations of indigenous human rights in Ireland for centuries before and after Cromwell, causing Irish people to be regarded as social and intellectual inferiors by the English power elite. Unsurprisingly, then, the anonymous Irish rebel ballad, of the kind epitomized by "Arthur McBride," "Dunlavin Green," and "Whiskey in the Jar" projects a strong anti-colonial strain, similar in some respects to the Scottish border ballads of heroic resistance and tragic defeat by the old adversary, England.

${ }^{2}$ Lloyd, Folk Song in England (London: Faber \& Faber, 1967 [2008]), 231. 
Colin Neilands' 1992 article on the Irish broadside ballads, based on archival research, traces the genre back to the early 17 th century in Ireland, and notes how an "early link between broadsides and nationalist politics continued and developed throughout the nineteenth century." English, rather than indigenous Irish language, was the more common medium of composition. Neilands argues that in Ireland the broadside "reached its zenith in the nineteenth century," and remained a popular form, particularly for social protest and satire. Comparing English broadside ballads with those in Ireland, Matthew Hodgart has observed how the popularity of the latter flourished even as that of the former began to wane:

During the nineteenth century broadsides continued to be written and sold in vast numbers, but the literary quality of the London popular muse declined. It was otherwise in Ireland, where the political situation and the national talent for song kept the broadside alive from the Rising of 1798 to the Troubles of the 1920 s. $^{5}$

Despite being regularly suppressed by the authorities, the ballad-singing tradition persisted into the twentieth century in Ireland, with singers performing in the open air at fairs and markets and later also in pubs. By no means all such ballads were politically motivated, but the practice tended to reflect political tensions and loyalties across both sides of the religious and political divide. The republican rebel songs are closely related to the popular street ballad tradition, and time-honored songs like "The Wearing of the Green," "The Minstrel Boy," "A Nation Once Again," "Follow Me Up to Carlow," "The Rising of the Moon" and "The Wind that Shakes the Barley"-all synonymous with the Republic's long struggle for self-determination-belong to this rich ballad heritage. More recent interpreters of the rebel ballad tradition, such as the Christy Moore, The Pogues, Derek Warfield, Sinéad O'Connor, and Seanchai and the Unity Squad have not just maintained the vibrant—and, in some quarters, still controversialtradition, but have also made signal contributions of their own to it.

Moore (Christy being the typical Irish short form for Christopher) was born in 1945 in County Kildare in the Republic of Ireland into a musical family on his mother's side. He began his music career as a solo performer, achieving recognition with his solo album "Paddy on the Road" in 1969. He subsequently became a founding member of Irish folk-rock bands Planxty in the 1970s and Moving Hearts in the early 1980s, resuming his solo career later in the 1980s, supported by fellow Irish musicians Donal Lunny and Declan Sinnott from the earlier bands. His work crosses popular music boundaries, and his broad repertoire includes whimsically humorous, bawdy, and irreverent numbers and beautifully melodic compositions, but its earliest influences come from traditional ballad roots. Moore's indebtedness to a thriving twentieth century ballad practice in Ireland can be heard in the vocal style that he has honed over a long career performing an extensive repertoire. It derives, in part, from the work of the Clancy Brothers and Tommy Makem, as well as the Dubliners, all of whom had been popularizing more traditional Irish songs and ballads in the 1950s and early 1960s when Moore was assimilating influences. Most of all, however, his love of the ballad genre can be traced back to the profound impact that itinerant Kildare balladeer, John Reilly, exercised upon his imagination. Reilly's powerful renditions of traditional ballads “The Well Below the Valley," "Lord Baker," and “The Raggle Taggle Gypsy” were never forgotten, and the ballads were adopted into Moore's own repertoire after the traveler-singer's premature death in 1969.

\footnotetext{
${ }^{3}$ Colin Neilands, "Irish Broadside Ballads: Performers and Performances," in Folk Music Fournal 6, no. 2 (1991), 209.

${ }^{4}$ Ibid., 209.

${ }^{5}$ Matthew Hodgart, Introduction to The Faber Book of Ballads, (London: Faber \& Faber, 1965), 21.
} 
Moore's is a style, therefore, that imbues the Irish ballad heritage with a contemporary voice. His book One Voice: My Life in Song is a retrospective meditation on his relationship with the songs he sanghis own compositions, interpretations of traditional songs and songs by other composers-as well as with his audiences over his half-century-long career. For Moore, as with the ballad-singers and writers themselves, the categorization of folk song or ballad, or of national or cultural derivation, is immaterial. It is the meaning that the song carries and the associations that listeners have with it that ensure its relevance and its longevity. As he explains in the book with reference to his censored and subsequently banned song about a tragic fire in a night-club in Ireland, "They Never Came Home": "I used Woody Guthrie's technique of describing the events to create not only a picture of the event but also the underlying inequalities and injustice and blatant discrimination that still exist in our society."

As this statement makes clear, what motivates Moore's songs and ballads covering a range of topics, including colonization, misogynist patriarchy, the exploitation of working people and the suppression of disadvantaged minorities by the wealthy and powerful, is a deep commitment to social justice, political consciousness, and basic human decency. At his most controversial and committed, singing of resistance against bigotry and discrimination in Northern Ireland during the euphemistically named Troubles of the 1970s and 1980s, and defending in song the victims of British injustice after the Guildford and Birmingham bombings in songs such as "Scapegoats," Moore was sometimes perceived in Britain as a terrorist sympathizer, and was harassed by the Special Branch police. Although by no means the most radical and uncompromising voice of political song in Ireland, given that there has always been a strong rebel streak in its folk music and ballads, Moore has probably had the highest profile, making him, at times, a controversial figure. No other Irish singer engages as critically as he does with such a wide range of sociopolitical issues.

Even in his native Ireland, his songs tended to tell too many home truths about the sexual liberties taken by members of the Catholic Church (with the complicity of the country's past governments) and widespread abuses against women and children, as well as against under-privileged social minorities such as travelers or gypsies, for him to be a popular and comfortable figure. The acute sensitivity toward his lyrics on either side of the Irish Channel during this period can be exemplified by the banning of his whimsically anachronistic song "St. Brendan's Voyage" by the BBC purely because it included a reference to the British-administered territory of Gibraltar; not only a contentious issue between Britain and Spain in terms of its sovereignty, the "Rock" had also featured in news reports in the late 1980s relating to the extra-judicial execution of three unarmed IRA (Irish Republican Army) members by the UK's shadowy SAS (Special Air Services) commandos in the so-called "Flavius" operation, an action subsequently judged unlawful by a 1995 judgment at the European Court of Human Rights. Such was the paranoia surrounding this event that Moore's fanciful allusion to the peregrinations of the sixth-century Irish sailorsaint were, bizarrely, perceived as conveying a subversive subtext.

Remarkably, in his mellower, more balanced old age after a somewhat turbulent life on the road, he has metamorphosed into a national treasure (frequently voted the Irish Republic's most popular singer), and was even interviewed in 2016 for a piece in the Arts Section of that bastion of British conservative values, The Daily Telegraph. His popular repertoire of disarmingly comic songs, the relative thaw in relations in Northern Ireland, and the relative vindication of some victims of abuse by the authorities in recent years, have all helped to alter the partisan perception of his controversial and edgy performing

${ }^{6}$ Moore, One Voice: My Life in Song (London: Hodder \& Stoughton, 2002), 168. 
persona of earlier decades. In addition, his felicitous turn of phrase and inventive imagery, as well as his ingenuity in investing stock expressions with fresh nuances of meaning, have continued to reinvigorate his own songwriting and his idiosyncratic interpretation of the songs of others. Unsurprisingly, the Telegraph interview concentrated more on his writing habits and his lifelong interest in various sports, and avoided the political interventions represented by his more engagé songs with their direct commentary on social injustices.

Some commentators on the ballad, such as Larryetta M. Schall for example, have differentiated between the quality of vagueness in the traditional, medieval ballad (deploying metaphor or indirect allusion as devices to suggest analogies between one period and another) and that of specificity in the broadside or political ballad, often referencing particular historical incidents. According to Schall in her article "The Ballad as Vehicle for Social Protest," the protest song of the 1960s had much in common with the traditional ballad's penchant for vagueness and universality. For her the protest song, by contrast, "is ephemeral, for as the problem is solved or disappears from public attention, either the song is forgotten, or its original meaning and purpose are lost." " Quite apart from Schall's cherry-picked examples, which exclude some of the great single-issue ballads by Seeger, Dylan, Ochs, and others, it is clear from looking closely at examples of the Irish ballad tradition that the vague and the specific varieties exist side by side.

Some of Moore's most popular songs fall squarely within this category of the specific, and in several of his most effective ballads of sociopolitical and sociohistorical protest, to be discussed, his technique relies on naming, a device he uses to brilliant effect. Moore's approach is that of the activist: he has sung for many social and political causes in his time, including his support for the hunger-striking, blanketwearing inmates of the notorious British H-Blocks in Maze Prison in Northern Ireland; his song lyrics alternate between plain description and name-referencing on the one hand and evocative lyrical imagery on the other. Five exemplars of his work are selected for analysis: these are all ballads, and are representative of different phases of his career to date. They provide the reader a cross-section of his own compositions (three) and ballad-style songs of other songwriters (two). Although only one title, "The Ballad of Patrick Murphy," adopts the generic nomenclature of ballad, the other four are all modern ballads in structure, style, narrative technique, and sensibility.

Moore's repertoire is too vast to discuss at length within the scope of this study, but his book, One Voice: My Life in Song, and his website, featuring his song lyrics, both offer opportunity for a more comprehensive exploration of his work. The aim of this paper, rather than attempting such a comprehensive commentary, is to discuss and analyze in some detail a limited number of iconic songs from his extensive repertoire that span his career up to his most recent album release. All of them are illustrative of the balladeer at the height of his powers of lyrical and/or vocal expression, commenting on key moments of Ireland's history, whether in the singer's lifetime or in the fairly recent past. These case studies are chosen to support the contention that the modern ballad remains a viable option for singersongwriters and interpreters interested in exploring sociopolitical themes and narratives that challenge establishment discourses.

\footnotetext{
${ }^{7}$ Schall, “The Ballad as Vehicle for Social Protest” in Studies in Popular Culture, Winter 1977, 27.
} 


\section{Analysis and Discussion of Five Ballads from Moore's Repertoire}

\section{“Ninety Miles to Dublin Town,” H-Block, 1978 (also known as “Ninety Miles from Dublin”)}

The ballad "Ninety Miles to Dublin Town" was written by Moore at the height of the civil strife in Northern Ireland to feature on a compilation protest album of songs by various politically engaged Irish artists. The song was significant in that it catalogued abuses inflicted on men and women prisoners incarcerated in the Armagh and Long Kesh H-Block prisons (the name reflecting their architectural configuration) by the British authorities in Northern Ireland in the 1970s and 80s. In his song Moore indicts the blatant political bias of these courts as well as their suppression of the right for political prisoners to fair trial by jury. The inmates considered themselves prisoners of war in the Provisional Irish Republican Army's legitimate struggle for political representation and for an end to British rule in Northern Ireland. Specifically, the song records the so-called "Blanket Protest" of the early 1980s, which culminated in two major hunger strikes in which ten prisoners died: "Sentenced in a Diplock Court, my protest it began / I could not wear their prison gear, I became a Blanket Man." ${ }^{8}$ Moore was later to celebrate the memory of perhaps the most famous of the H-Block protesters, elected Fermanagh-South Tyrone MP Bobby Sands, by setting music to the lyrics of two ballads he wrote during his incarceration. Both became firm favorites in the singer's repertoire ${ }^{9}$ after Sands' much-publicized death on hunger strike in 1981. Despite their controversial ethos, Moore has always been unrepentant about including them in his catalogue and performance set.

The lyrics of "Ninety Miles to Dublin Town" plainly document the various indignities, humiliations, and tortures to which the prisoners were routinely subjected. These included being badly beaten, held in scalding water, having skin torn from the body by guards with deck scrubs, and suffering degrading mirror searches after being stripped naked. While the subject persona who experiences these abuses remains unnamed, and is thus representative of all political regimes that regularly infringe the Geneva Convention on the rights of prisoners-including supposedly democratic ones-the painful and humiliating practices are specifically and accurately referenced. Moore's desire to catalogue the injustices results in a typically balladesque poetic license that is discernible in the archaic-sounding irregular syntax of some of his lines, for example: "The Blanket Protest must not fail till our status we regain."10

The song's tight rhyming scheme, with strong couplet rhymes in each of the conventional four-line verses, calls for the poetic license of traditional balladry; the absence of a chorus (a simple refrain line in the first and last verses states that "it's ninety miles to Dublin Town") equally imbues it with a strong ballad feel. This is further accentuated by the song's uncomplicated melody and functional harmony, revolving around two basic chords, I and IV - with sparing use of chord V in cadences—and a rhythmic emphasis on even beats to facilitate lyrical clarity. This directness has the effect of promoting vicarious sympathy for the prisoner persona, and is enhanced by the measured, earnest style of Moore's delivery, while the plaintive harmonica "outro" reinforces the ballad's emotional appeal nonverbally. His closing observation that the Americans have done more to intervene in support of the political prisoners in the $\mathrm{H}$ Block cells than the authorities across the border in Dublin also involves a call for solidarity in his own

\footnotetext{
${ }^{8}$ Moore, "Ninety Miles to Dublin Town," third verse. The "blanket protest" was an act of defiance according to which IRA prisoners refused to wear the normal prison uniforms worn by convicts, and consequently, lacking clothes, wrapped themselves in their bedclothes. Such prisoners were referred to as being "on the blanket."

${ }^{9}$ The two ballads, "McIlhatton" and "Back Home in Derry," are featured on Moore's 1983 album "The Spirit of Freedom."

${ }^{10}$ Ibid., fourth verse.
} 
country: "Pay attention Irish men and Irish women too / And show the Free State government its silence will not do." 11 This critique of political complicity and pusillanimity on the part of the Irish government becomes a recurrent motif of Moore's ideological commitment from the late 1970s onwards. So, too, does the act of remembrance invoked in his final line: "Remember ninety miles away I'm in my H-Block cell." ${ }^{12}$

\section{"Viva La Quinta Brigada," Ride On, 1984}

"Viva la Quinta Brigada" from Moore's 1984 Ride On album is equally an affirmation of ordinary, but at the same time extraordinary, men. Listed as "Viva la Quince Brigada" in later recordings, since the brigade was actually designated the 15th of the Spanish Republican forces, it is a heroic genre ballad dedicated to the Irishmen who fought in the Spanish Civil War against Franco. The title was partly inspired by a Spanish song about the war, "Viva la Quince Brigada," a variant on the better-known song sung by the Republican side, "Ay Carmela." It shares its title with an antifascist Pete Seeger song on the Civil War theme, written in Spanish. For his part, Moore composed the song having read an account of the events in a book entitled Connolly Column by one of the survivors Michael O'Riordan, a source that Moore has freely acknowledged.

The song celebrates the bravery and determination of the Irish socialist volunteers, a smaller contingent within the 15th International Brigade. They were known as the Connolly Column, named after James Connolly, who was an Edinburgh-born Trades Union leader. He settled in Ireland and together with Patrick Pearse spearheaded the Easter Rising of 1916 against the British colonial regime, an action for which he was executed by the British Army. He is the subject of a ballad simply entitled "James Connolly" that has featured regularly in Moore's repertoire. The ballad, the words of which were written by Cork poet Patrick Galvin, characterizes Connolly as "this good man" and "the hero of the working man"13 The song's central conceit_-in common with many such heroic ballads—is that Connolly is not dead, but departed, gone to "organise the union / That working men might yet be free." 14

Naming or listing is a common feature of outlaw ballads and others, akin to the epic poetic device of cataloguing. This is a core compositional element of "Viva La Quinta Brigada." By naming some of the 200-strong band of men, including their charismatic leftist leader Frank Ryan-himself the subject of Sean Cronin's study Frank Ryan: The Search for the Republic-Moore offers his own memorial to Ryan and to those who joined the International Brigade to fight on the Republican side. Nineteen men, including Ryan, and one anonymous Christian Brother, are listed by name in the song, no mean feat within ten verses. Moore also names the leader of the pro-Falangist Blueshirts, Eoin O'Duffy, the recruitment of whose troops for Franco was strongly supported by the encomiums of the Catholic Church and establishment press propaganda. "The word came from Maynooth [the principal Catholic seminary in Ireland] support the Nazis / The men of cloth failed again," sings Moore, but he stops short of indicting the bishops, the politicians, and the media magnates by name, opting deliberately for vagueness here, in order to concentrate on the deeds of Ryan's men. "Though many died I can but name a few." 15

Ryan's own seemingly ambivalent situation—stuck in Berlin during WWII, having narrowly escaped

\footnotetext{
${ }^{11}$ Ibid., seventh verse.

${ }^{12}$ Ibid., eighth verse.

${ }^{13}$ Galvin and Moore, "James Connolly," second verse.

${ }^{14}$ Ibid., first and seventh (final) verses.

${ }^{15}$ Moore, "Viva la Quinta Brigada," eighth verse.
} 
execution by the Fascists and owing a debt of gratitude for his life to the Nazis-was once the subject of fierce debate in Ireland north and south. ${ }^{16}$ Moore doesn't lionize him, but references him on a par with his comrades. To indicate that this comradeship was idealistic and progressive in spirit, and crossed the deep divides of sectarianism and residual bitterness springing from the Irish Civil War of the 1920s, he juxtaposes two men of diverse religious denominations and allegiances, Bob Hilliard, a Church of Ireland pastor (Protestant) and an unknown young Christian Brother (Catholic), and sings that "side by side they fought and died in Spain"17, commemorating them in a single verse.

The song has many typical ballad features in its regular, four-line, default-pentameter structure, as well as a basic up-tempo, three-chord strumming pattern in its nine verses. The sinuous and syncopated guitar intro and "outro" endow it with a Spanish tenor, enhanced by the rhythmic hand-clapping and improvisatory quality of the latter, which serve to offset the elegiac mood. Moore's reference to the Spanish Republican watchwords "no pasarán" ("they shall not pass") and "adelante" ("forward") intensifies this Iberian ambience. The emotional highpoint of Moore's composition is provided by the combination of melodic hook and non-narrative lyrics that marks its chorus: the minor chord harmony on the line "Adelante was the cry across the hillside" imbues the lyric with a sense of pathos, since both singer and listener know the outcome of the struggle; this is followed by a musical resolution in the major chord progression cadence of the last line, as well as a resolution of remembrance: "Let us all remember them tonight." 18

One interesting departure from ballad convention is that here the poetic voice is not the vague, allpurpose and impersonal "I" narrator mediating the events related in the ballad, but categorically that of the singer and composer in his own person, who declares his interest in the opening lines: "Ten years before I saw the light of morning / A comradeship of heroes was laid." ${ }^{19}$ As in a significant number of his songs,though by no means all-Moore's minstrelsy implies his own continuing ideological commitment to the cause of anti-fascism through the examples set by these men.

\section{“Ordinary Man” - Ordinary Man, 1985}

The song "Ordinary Man" has been a core component of Moore's set listings since he first adopted it in his repertoire, and used it as the title of his 1985 album, Ordinary Man. It was originally pressed into his hand as a cassette recording by a British singer from Grimsby named Peter Hames after one of Moore's many British concerts. Hames's ballad is an indictment of the savage cuts to employment imposed on British workers during the Thatcherite class war of the 1980s. The melody and lyrics touched a chord in Moore, and his incisive but empathic recording of it transformed Hames's little-known song into a classic protest ballad against a rapacious neoliberal capitalism. Moore's plangent delivery is endowed with a lilting quality, thanks partly to the internal rhyming in the longer lines and partly to the echoing refrain after each of the eight-line verses. Harmonically more nuanced than the typical traditional ballad, the song opens

\footnotetext{
${ }^{16}$ After being captured by Franco's troops fighting for the International Brigade in 1938 during the Spanish Civil War, leftist Republican former newspaper editor Ryan was condemned to be executed, but was saved and held hostage by German Military Intelligence. He was forced to spend the war years in Berlin, which led to allegations of his collaboration with the Nazis for the sake of strategic advantage to the Irish Republican cause. These allegations are discussed by Sean Cronin in his biography Frank Ryan - The Search for the Republic (Dublin: Repsol Publishing, 1980). See also Mark M. Hull's study Irish Secrets: German Espionage in Wartime Ireland, 1939-1945 (Dublin: Irish Academic Press, Ltd., 2004).

${ }^{17}$ Ibid., fourth verse.

${ }^{18}$ Ibid., chorus.

${ }^{19}$ Ibid., first verse.
} 
with a fast harmonic rhythm, a repeated device employing rapid chord changes, which invests it with a sense of urgency from the start. The verse is rooted in the minor key, but this is followed by an arresting minor-to-major lift at the beginning of the fifth line of each verse, heralding a temporary variation in mood. ${ }^{20}$ As for the lyrics, simplicity and directness are the key qualities epitomized by the "I" persona of the song, who recounts how he has been "stripped bare of dignity and pride" 21 by the targets of his accusation, "the captains of industry," the "you" at whom the final lines are directed.

Although the unidentified ordinary man has a specific singularity and specific domestic responsibilities- "I watch my darling wife, tryin' to make the best of life / God knows what the kids are going to do"-he is also invested with a representative, Everyman spirit: "There's one law for the rich, one for the poor." 22 Moore's interpretation responds to the song's potential for making the intensely personal predicament of the "I" persona a universal call for human dignity and solidarity. While the ordinary man of the title seems "condemned" to a life of miserly benefits, despite his frustrated efforts to find work, his condemnation of those responsible for his fate is palpable: "Now as long as I live / I never will forgive." 23 Even in the asset-stripping, monetarist context of the 1980s, the faceless market forces of globalization made it impossible to identify specific figures, much as today.

Unlike the so-called "industrial ballads" of the nineteenth century's Industrial Revolution, which often name-checked factory owners, scabs, and the towns in which the disputes occurred, global monopoly capitalism, as the song notes, wreaks its havoc on the worker with an anonymity that is as impenetrable as the authorship of the medieval ballads. At the same time, the absence of names or specific references in the lyrics and the powerful melodic line enhance the universal appeal in the lyrics, and endow the song with the quality of a political protest anthem. Plaintive pedal-steel guitar-work, including some deft fills and soaring solos by Moore's longtime accompanist and musical director, Donal Lunny, underpin the meaning of the lyrics and endow them with a bittersweet reflective quality, particularly in the instrumental "outro" and fade. The ballad's theme and message are as relevant today as they were when it was first performed, as is clear from its continued popularity in Moore's concerts worldwide.

\section{“Minds Locked Shut" - Graffiti Tongue, 1996}

The naming device also features in the elegiac ballad "Minds Locked Shut" from the 1996 album Graffiti Tongue. It is Moore's song of remembrance for Bloody Sunday when 14 civil rights marchers from the Catholic community of Northern Ireland were gunned down in cold blood by British soldiers on 30 January 1972 in Derry. Seemingly a historical ballad of the so-called "Troubles," the song acquired fresh topicality during media coverage of the Saville Inquiry in Britain the findings of which were published in 2010, overturning the political whitewash of the 1972 Widgery Report. ${ }^{24}$ Following thirty years of denial of responsibility by the government, a verdict of unlawful killing by British soldiers without provocation or justification was published in the report, and the then British Prime Minister Cameron issued a formal

\footnotetext{
${ }^{20}$ The song uses an Am/F/G/Am progression, followed by an $\mathrm{F} / \mathrm{G} / \mathrm{Am} / \mathrm{F}$ sequence in the fifth line and an effective variation from $\mathrm{F}$ to E major (instead of $\mathrm{F}$ to $\mathrm{Am}$ ) in the sixth line, which briefly introduces a short-lived emphatic, determined tone, before the more downbeat minor tonality reasserts itself in the final two lines.

${ }^{21}$ Hames and Moore, "Ordinary Man," final verse.

${ }^{22}$ Ibid., ninth verse.

${ }^{23}$ Ibid., final verse.

${ }^{24}$ See www.bloody-sunday-inquiry.org.uk for The Bloody Sunday Inquiry and Report and http://cain.ulst.ac.uk/events/abstract/72bsun.htm for an overview of the hastily prepared 1972 Widgery Report, which was superseded from June 15, 2010, onward by the findings of the Saville Report.
} 
apology. Predictably, there was a backlash against the report and the apology by those with a vested interest in obfuscating the act of state terror that Bloody Sunday represented. Moore's 1996 song cites all fourteen names of the unarmed and peaceful marchers killed by the live ammunition used by the paratroopers. In the Encyclopedia of Social Movement Media, Bill Rolston references the song, and notes that "Few artists other than Moore were consistent about including state violence in their condemnations." 25

Moore references the violence but in more impersonal terms, without pointing a finger at specific individuals. His technique here is rather different from his earlier socio-political ballads, inasmuch as it does not present a binary opposition of values, as "Viva la Quinta Brigada" and other Moore songs of resistance have tended to do. Rather, he evokes an elegiac mood of remembrance, as opposed to a heroic, celebratory one. By downplaying the role of individuals and employing the impersonal constructions, "it happened on a Sunday afternoon," 26 "there was gunshots, stones and bullets," ${ }^{27}$ "and there remains," 28 etc., he creates a space in which shared responsibility for the ensuing years of violence and hatred can be contemplated. In its musical delivery the slow ballad connotes and underscores the rhythm and tempo of the events depicted in the song. ${ }^{29}$ Thus, the peaceful intention of the marchers, metonymically conveyed by the calm weather, is evoked over long gently strummed chords of the slow introduction; however, as the march motif is introduced in the line, "on a perfect day for walking," a more deliberate and accelerated rhythm is heard on the word "walking," intended to imitate the regular collective step of the marchers.

On the four-times-repeated refrain, "And then our minds locked shut," the percussive, staccato guitar chord on the significant word "shut" creates a memorable musical metaphor of the act of locking. This repetitive delivery of the ballad refrain conveys the subsequent intransigent polarization of views and attitudes, and implies the prison of the mind, as distinct from the physical incarceration of the H-Block prisons. Moore recites the litany of names of the fourteen who died, intoned evenly in pairs over the simple and repeated sequence of chord I (tonic) and chord IV (subdominant) of the verse; after an incantatory exhortation to the listener, "Let us remember," he ends where he began with a reprise of the ballad's slow introduction: "On a lovely bright crisp winter's afternoon / On a perfect day for walking" ${ }^{30}$ Again, the tempo matches the mood and meaning to perfection, but instead of accelerating the beat on the word "walking" there is a rallentando and solemn final chord, implying the curtailment of the march and a sense of finality.

Let us also remember that Moore's song pre-empted the thaw in relations and ultimately the long and difficult peacemaking process that began in 1998, and concluded with the vindication, represented by the publication of the Saville Report. When he wrote the song, as he notes in his book, what was truly shocking was "the number of English people who believed that the fourteen shot dead on Bloody Sunday were Irish Republican Army men." ${ }^{31}$ He goes on to comment, "once our minds lock shut it can take too much to prise them open again." ${ }^{32}$ His use of the possessive adjective "our" rather than "their" is perhaps the most significant feature of all in these song lyrics. Truth and reconciliation are hinted at in his prescient ballad, noble words that mask a painful process. As history tells us, what followed was the

${ }^{25}$ Rolston, "Northern Ireland," in "Popular Song and Protest" in The Encyclopedia of Social Movement, ed. J. Downing (New York: Sage Publications, 2011), 415.

${ }^{26}$ Moore, "Minds Locked Shut," first verse.

${ }^{27}$ Ibid., second verse.

${ }^{28}$ Ibid., bridge.

${ }^{29}$ See live solo performance by Moore at https://m.youtube.com/watch?v=lqdZ2NMq3g4.

${ }^{30}$ Ibid., final verse.

${ }^{31}$ Moore, One Voice: My Life in Song, 206.

${ }^{32}$ Ibid., 206. 
inexorable move toward the fairer and more representative political system that Northern Ireland enjoys today. "Minds Locked Shut" thus represents a paradigm shift for a man sometimes seen as "an agitprop balladeer" by his singer-songwriter peers, a role he readily assumed in the earlier phase of his career.

\section{“The Ballad of Patrick Murphy" - Lily, 2016}

Now an internationally acclaimed performer of hybrid musical influences and diverse styles, Moore remains a dedicated balladeer, as "The Ballad of Patrick Murphy," another ballad of injustice and remembrance, on his 2016 album Lily indicates. In the 1990s the recognition that the time had come to put aside some of the rebel ballads of indictment, and to embrace reconciliation, is reflected in these lines from his song, co-written with Bono and The Edge of U2, "North and South of the River," which is featured on Graffiti Tongue, the same album as "Minds Locked Shut": "There's an old church bell no longer ringing / And some old songs are not worth singin'."33 By contrast, 2016 marks the centenary of the Easter Rising, and some of the songs on Lily reflect the view that the past one hundred years of Ireland's history should not be consigned to oblivion.

Just such a new song, John Spillane's 2011 "The Ballad of Patrick Murphy," has rapidly become an integral component of Moore's performance set. ${ }^{34}$ The song recounts a 1911 event in the Cork area in the south-west of Ireland, but is filtered through the prism of a contemporary narrative consciousness, stressing the importance of remembrance. In this respect, like the more personalized ballads discussed above, it eschews the impersonal, virtually ahistorical viewpoint adopted by the many anonymous or forgotten composers of traditional ballads. Spillane wrote it for a wreath-laying memorial gathering in the town of Passage West where he now lives and where Patrick Murphy was born and worked as a fisherman to support his family (consisting of wife and seven children, as the song specifies). The ballad chorus emphasizes the importance of salmon fishing in the River Lee to the local economy and, a hundred years ago, to basic subsistence: "They lived beside the river / At the turning of the tide / They lived beside the river / By the river they lived and they died." He was invited to write and sing the ballad at a 2011 event in Passage West to mark the centenary of "the killing of Pat Murphy / By a bullet from the bailiff's gun." 35 The bailiffs based at Blackrock Castle, known as the Murricawn, and characterized as "gangsters in the service of the Crown" (i.e. the British colonizers), are indicted in Spillane's song-text for their bloody deed.

The song is a good illustration of how ballad music can be spare and functional, and at the same time provide an apt vehicle for communicating meaning and affect. Its repetitive four-line, tetrameter versestructure recounts a simple narrative that underscores the simple lifestyle of the subject. As with many ballads, the emotional impact is transmitted through the chorus-refrain, which begins the song in unassuming fashion, initially employing the same notation and pitch as the verse does. In Moore's version, when the chorus-refrain is heard in its subsequent iterations, the lines "They lived beside the river / At the turning of the tide" are sung an octave above the tonic, harmonized by backing vocal accompaniment. This shift endows the song narrative with a much more heartfelt quality, and draws the listener in more closely to its affective ambit. In the second half of the chorus, variation is provided by the gently lilting,

\footnotetext{
${ }^{33}$ Moore, Bono, and The Edge, "North and South of the River," fourth verse.

${ }^{34}$ See for example the concert review in Irish Examiner, July 6, 2015: http://www.irishexaminer.com/ireland/video-magic-ofchristy-moore-lights-up-marquee-340924.html and the album review of Lily, May 21, 2016 at http://www.irishexaminer.com/lifestyle/artsfilmtv/album-review-christy-moore--lily-400780.html in the same newspaper.

${ }^{35}$ Spillane, "The Ballad of Patrick Murphy," fifth verse.
} 
descending triplet figures of the phrase: "ri-ver-they / lived-and-they" before the perfect cadence, concluding with the resolution and emphatic final note of "died."

Spillane's original text places the emphasis on forgiveness and reconciliation, and he shaped the song accordingly, imagining Murphy forgiving his assailants on his death-bed, although his text observes that "The people still remember / That justice was not done." ${ }^{36}$ In Moore's rendition the song retains its quiet dignity; however, he opts to omit the verse that preaches a spirit of forgiveness toward those responsible, and even accentuates the cold-blooded killing of the fishermen by foregrounding intent in his line "they murdered Patrick Murphy" ${ }^{37}$ replacing Spillane's less damning: "they shot Pat Murphy down." This is a good example of Moore's predilection for authenticating his own version by making textual changes to anonymous ballads or approved revisions to songs composed by fellow songwriters. Moreover, it reflects Moore's tendency to denounce indigenous Irish collaborators in the history of England's imperialist mission in Ireland to a greater extent than he does the actions of those who came from across the Irish Sea. The song "Oblivious," written by Mick Blake, which precedes "The Ballad of Patrick Murphy" on the Lily album, represents a withering critique of the Republic's shortcomings, recalling some of the scathing commentary of Moore's 1970s and 1980s protest ballads in its centenary commemoration of the Dublin Easter Rising of 1916: “Just like we're oblivious / What does it take to make us angry?” he enquires. Responding to this rhetorical question Blake (and Moore as song interpreter) target the Irish establishment with a line recalling the ultimate sacrifice made by the insurgents: "All that they killed and died for / Has been squandered by scoundrels and fools." 38

Moore respects the ballad-singer's craft in both English and Irish, as his version of the Padraig Stevens song "The Tuam Beat" on Lily makes abundantly clear: "Once upon a golden age / Singin' songs was all the rage / Songs for glory, songs for fun / Sad songs in the native tongue." ${ }^{39}$ Ironically, perhaps thinking of his own politically engaged protest songs among other traditional rebel songs in his catalogue, he reassures the listener, tongue firmly in cheek: "Here's a song to set you free / From all that dull history," new-reworked for a contemporary audience - and correspondingly, as time passes, the new songs become the old. Thus the artist's work affirms the creative spirit of songwriting that is an intrinsic part of the bardic tradition of Ireland; whether interpreting the new ballads of others, as in "The Ballad of Patrick Murphy," "Oblivious," and "The Tuam Beat," or claiming the Irish ballad tradition as his birthright in self-penned songs, Moore's contribution to modern Irish popular music has been estimable.

\section{Conclusion}

To conclude where we started with the reference to Raymond Williams's critical insights in The Long Revolution, it is worth noting that Moore's 1987 album Unfinished Revolution explores the potential for a revolution in the mind, rather than one made solely by weapons and force. The album, which included some of his highly regarded interpretations of protest and solidarity songs such as "Biko Drum" by Wally Page and the eponymous "Unfinished Revolution" by Peter Cadle, took a wider, more international view

\footnotetext{
${ }^{36}$ Ibid., seventh verse.

${ }^{37}$ Moore, "The Ballad of Patrick Murphy," recorded alternative version on the 2016 album Lily. In the fifth verse of Moore's version the lyric employs the more emotive and accusatory term "murdered."

${ }^{38}$ Blake, interpreted by Moore, "Oblivious," track 7 on the 2016 album Lily, final verse.

${ }^{39}$ Stevens, interpreted by Moore, "The Tuam Beat," track 2 on Lily, first verse.

${ }^{40}$ Ibid., second verse.
} 
of the revolutionary project than was evident in earlier phases of his career, when the focus was more on emancipation through resistance purely in the context of the Irish Republic and Northern Ireland.

In this respect Moore's affinity with Williams's innovative ideas on the close relationship between arts and culture and democratic change becomes apparent. One can see a correlation between the long evolution of the folk ballad form and the long revolution in sociocultural literacy that lies at the heart of Williams's groundbreaking diachronic study. Both are, arguably, works in progress, but both are motivated by an emancipatory impulse for social and individual enlightenment. The ballad can still be emblematic of demotic culture, and, in its own way, reflective of an aspiration for social mobility and engagement, as envisioned by Williams; it also remains a versatile vehicle for popular expression, one that can interact productively with other musical genres and styles. As with Williams's critical intervention, Moore's writing and singing is directed at the "ordinary man," and increasingly—under the influence of feminist thinking and values in songs such as "Burning Times" and "God Woman"-at the ordinary woman.

Williams's structure of feeling theory sees the cultural tradition and form, or structure, and the contemporary spirit, or feeling, of the cultural product as being complementary, and capable of generating relevant sociocultural meanings at each fresh iteration in time and place. If we apply Williams's cultural taxonomy to the singer-songwriter's work, namely his structure of feeling concept and the tripartite paradigm of idealist, documentary and social expression, there is an evident interdependence between abstract cultural theory and concrete cultural practice. It is also clear that the naming or cataloguing device common to the ballad is a significant feature of Moore's methodology and one that reflects a documentary impulse in his writing and performance practices. Likewise, the social function, common to live music generally, but particularly important for songs that invoke a sense of ideological solidarity at live performances, is easily discernible. Moore makes a very insightful observation in One Voice that the social and documentary aspects of all the songs in his set, not just the ballads, are in a very real sense the common property of performer and listeners in the shared experience of the live concert:

While these songs are in performance they belong in the air. No one cares who wrote them while I sing them; they belong to us collectively. Writers and publishers own copyright, but the words out there are in the world vocabulary; where people think or speak, the words are floating back and forth. ${ }^{41}$

As regards any claim to a more elevated and idealist cultural tradition-a claim that Moore himself would undoubtedly find spurious - it has probably been conferred on him by now, whether he is comfortable with the honor or not. In his own modest Everyman persona, evincing respect for songs and ordinary folks alike, and singing out against oppression and injustice wherever they may occur, his life in music reflects the essence of one of Williams's early and influential essays, "Culture is Ordinary." As Williams observes in that essay: "At home we met and made music, listened to it, recited and listened to poems, valued fine language. I have heard better music and better poems since; there is the world to draw on. But I know, from the most ordinary experience, that the interest is there, the capacity is there." 42 This is precisely the attitude that characterizes Moore's continuing engagement with both his national and international audiences.

\footnotetext{
${ }^{41}$ Moore, One Voice: My Life in Song, 234.

${ }^{42}$ Williams, "Culture is Ordinary," in The Raymond Williams Reader, ed. , 24.
} 


\section{References}

“Abstract of Important Events - 'Bloody Sunday,' 30 January 1972.” The Widgery Report. http://cain.ulst.ac.uk/events/abstract/72bsun.htm.

Blake, Mick. "Oblivious.” Irish Folk Songs. Retrieved July 29, 2016. http://www.irish-folksongs.com/blog/oblivious-lyrics-by-christy-moore.

Chilton, Martin. "I search for the perfect word." Interview with Christy Moore in The Telegraph, Culture and Music Section, May 7, 2016. Retrieved July 29, 2016.

http://www.telegraph.co.uk/music/artists/christy-moore-interview-i-search-for-the-perfect-word/.

Cronin, Sean. Frank Ryan - The Search for the Republic. Dublin: Repsol Publishing, 1980.

Dermody, Joe. "Magic of Christy Moore Lights Up Marquee.” Irish Examiner, Monday, July 6, 2015.

Galvin, Patrick. "James Connolly.” Retrieved July 29, 2016. https://www.youtube.com/watch?v=$\underline{\text { IP7m4TuLTQ and http://www.christymoore.com/lyrics/james-connolly/. }}$

Hodgart, Matthew. Introduction to The Faber Book of Ballads. London: Faber \& Faber, 1965, 11-22.

Hull, Mark M. Irish Secrets: German Espionage in Wartime Ireland, 1939-1945. 2nd ed. Dublin: Irish Academic Press, Ltd. 2004.

Lloyd, Albert L. Folk Song in England. London: Faber \& Faber, 1967 [2008].

Moore, Christy. One Voice: My Life in Song. London: Hodder \& Stoughton, 2002.

Moore, Christy. The Christy Moore Songbook. With an introduction by Donal Lunny. Dingle, Co. Kerry: Brandon Publishers, 1984.

Moore, Christy. "If I Get an Encore," adapted version of original song lyrics by Nathan Carter, first verse. Retrieved July 29, 2016. https://m.youtube.com/watch?v=DAGC44ucIrM. See also "Encore" in Moore, One Voice: My Life in Song, 155-6.

Moore, Christy. “Minds Locked Shut.” Retrieved July 29, 2016. http://www.christymoore.com/lyrics/minds-locked-shut/.

Moore, Christy. “Ninety Miles to Dublin Town.” Retrieved July 29, 2016. http://www.christymoore.com/lyrics/ninety-miles-to-dublin-town/.

Moore, Christy. "Ordinary Man.” Retrieved July 29, 2016. http://www.christymoore.com/lyrics/ordinaryman/.

Moore, Christy. “They Never Came Home.” Retrieved July 29, 2016. http://www.christymoore.com/lyrics/they-never-came-home-stardust-song/.

Moore, Christy. “Viva la Quinta/Quince Brigada.” Retrieved July 29, 2016. http://www.christymoore.com/lyrics/viva-la-quinta-brigada/.

Moore, Christy, Bono, and The Edge. "North and South of the River." Retrieved July 29, 2016. http://www.christymoore.com/lyrics/north-and-south-of-the-river/.

Neilands, Colin. "Irish Broadside Ballads: Performers and Performances." Folk Music Journal 6, no. 2, 1991, 209-222.

O'Riordan, Michael. Connolly Column: The Story of the Irishmen who Fought for the Spanish Republic, 1936-39. 2nd ed. Torfaen: Warren and Pell, 2005.

Power, Ed. “Album review - Christy Moore, Lily.” Irish Examiner, Saturday, May 21, 2016.

Report of the Bloody Sunday Inquiry. http://www.bloody-sunday-inquiry.org.uk/. 
Rolston, Bill. "Political Song (Northern Ireland)." In Encyclopedia of Social Movement Media, edited by , 4145. New York: Sage Publications, 2011.

Schall, Larryetta, M. “The Ballad as Vehicle for Social Protest.” In Studies in Popular Culture 1, no. 1 (Winter 1977): 26-35.

Spillane, John. "The Ballad of Patrick Murphy.” Retrieved July 29, 2016. https://songoftheisles.com/2014/05/17/the-ballad-of-patrick-murphy/.

Stevens, Padraig. “The Tuam Beat.” Retrieved July 29, 2016. http:/www.shazam.com/track/106789732/the-tuam-beat.

Williams, Raymond. "Culture is Ordinary.” In The Raymond Williams Reader, edited by John Higgins, 1024. Oxford and Malden, MA: Blackwell, 2001.

Williams, Raymond. The Long Revolution. Calgary: Broadview Press, 2001.

\begin{abstract}
The ballad's longevity and endurance as a vital form of cultural resistance to prevailing orthodoxies, hegemonies, and power abuses are highlighted by the performances and recordings of contemporary Irish singer Christy Moore. As he recalls in his show-closing song "If I Get an Encore," he was "bitten by the ballad bug" in his formative years, and has continued throughout his long career to boost the popularity of a currently rather neglected and unfashionable form of Anglophone popular culture. In this essay I will analyze and discuss five examples of Moore's characteristic fusion of traditional ballads, classic modern ballads—such as those of Woody Guthrie and Ewan MacColl—contemporary ballads, and self-penned songs of protest and social critique. The selected ballads include "Ninety Miles to Dublin Town," written in support of hunger-striking prisoners in Northern Ireland, "Viva La Quinta Brigada," a tribute to Irishmen who joined the resistance against Franco in the Spanish Civil War, and "Minds Locked Shut," Moore's ballad about the Bloody Sunday events of 1972. The singer's distinctive vocal interpretation reconciles the idealist, documentary, and social facets of the ballad tradition in the persona of the "ordinary man," to reference one of the most popular protest songs in Moore's repertoire. Moore's work will be discussed in the light of the above three components of cultural evaluation proposed by the eminent cultural critic, Raymond Williams.
\end{abstract}

